\title{
Ozone and autologous therapies [abstract]
}

\section{Ruhi Cakir}

Mediozon Clinics. Istanbul, Turkey

\section{ABSTRACT}

\section{ठ OPEN ACCESS}

\section{Citation}

Cakir R. Ozone and autologous therapies [abstract]. Proceedings of The World Conference on Ozone Therapy in Medicine, Dentistry and Veterinary. Ancona (Italy). September 22nd - 23rd - 24th , 2017. J Ozone Ther. 2019;3(4):6. doi: 10.7203/ jo3t.3.4.2019.15396

Academic Editor Jose Baeza-Noci, School of Medicine, Valencia University, SPAIN

\section{Editor}

World Federation of Ozone Therapy, Bolgna, ITALY

\section{Received}

June 17, 2019

\section{Accepted}

December 08, 2019

Published

December 30, 2019

\section{Intellectual Property}

Ruhi Cakir.

This is an open access article distributed under the terms of the Creative Commons Attribution License (CC BY 4.0), which permits unrestricted use, distribution, and reproduction in any medium, provided the original author and source are credited.

\section{Author Information}

Barbaros Mah. Deluxia Palace D: 226 Atasehir / Istanbul

Phone: +902163681645

Fax: +902163694727

E-Mail: dr_ruhicakir@yahoo.com
Purpose. One of the proven effects of Ozone Therapy, is the releasing of Growth Factors from Platelets. Some other therapies can have similar effects. Autologous Therapies can be defined as "The therapy that is done by transferring cells, tissues, body liquids originating from the recipient rather than from donor." The purpose of this presentation is to give information on those therapies.

Discussion. There are several therapies in this group, such as Stem Cell Therapies, Dentric Cell Vaccine Therapy, Autologous immune enhancement therapy, etc. But most of them are so difficult that we can not practise at office conditions where some therapies can be done at small clinic and private offices. These are; PRP (Platelets Rich Plasma) / CGF (Concentrated Growth Factors) / PRF (Platelets Rich Fibrin). The differences among those therapies and common points are evaluated.

Results. All those therapies have some beneficial effects.

Conclusion. Integrative Medicine and Autologous Therapies look as future medicine. We can learn more on these therapies. 